\title{
The Enigma of Childhood the Profound Impact of the First Years of Life on Adults as Couples and Parents
}

\author{
Solan $\mathbf{R}^{1^{\star}}$ and Gaoni $\mathbf{B}^{2}$ \\ ${ }^{1}$ Tel Aviv University, Israel \\ ${ }^{2}$ Head of Department, Shalvata Psychiatric Hospital, Israel
}

The book deals with emotional development up to age three and its implications for adulthood, couple hood and parenting. The appearance of The Enigma of Childhood is a cause for celebration for all those who are involved in this area of psychology and with child development. The book details instructively, supplemented by countless examples, the appearance of the child's innate abilities, and how, in interaction with the environment, they are transformed from potential into actual characteristics, just as a small seed in suitable soil and with appropriate heat and light, turns into a spectacular plant. In reading the book you feel you are accompanying a pair of parents and their baby on a particularly interesting journey, and you are so drawn into the love story that you are sorry when the trip comes to an end.

My association while reading the book was of opening a hand-held fan decorated with a beautiful drawing, and the more you open the fan the more clearly you see the complexity of the drawing and feel a refreshing gust of wind.

The book is divided into two parts, each of which elaborates a series of basic concepts, the first connected to the oral phase (from birth to age 12-18 months), and the second to the anal phase (from age 12 months to three years). The book describes progression from one phase to the other by exploring major issues such as the development of narcissism, the development of object relations and feelings, and the development of the ego in terms of its adaptation and defense mechanisms. The central thesis of the book is that within every adult a child is hidden, and the influence of this child is decisive for the individual in the present as well as in the future.

In addition to its attention to familiar themes, the book also offers innovations and fertile ideas such as the development of narcissism and its role as an emotional-immune system safeguarding self-familiarity, just as the physiological immune system safeguards the familiar in the protein of the cell. Dr. Solan views narcissism as the fifth component in the structural model of the personality, in addition to the four components generally referred to in the literature (id, ego, superego and ego ideals). This claim is based on deep imprinting that narcissism leaves and its fundamental influence, similar to the other components of the personality, on the development of individuation and the way people emotionally conduct their daily lives.

Healthy narcissism safeguards the familiar in the self and prevents the invasion of feelings of strangeness. The familiarity is tempting and feels close, while the strangeness and the otherness are perceived as unforgiving. The proper functioning of narcissism consolidates individuation and self-integrity. Impaired functioning leads to selffragility, a false self, the development of narcissistic personality disorders, perversions, etc. This impaired functioning constitutes the foundation for the appearance of symptoms that Dr. Solan refers to as emotional "auto-immune" diseases, such as self-induced failure, hairpulling, nail-biting, various addictions and even suicide.

Dr. Solan explains "jointness" object relations between separate individuals, showing how different these are from Mahler's symbiosis, and also provides insights into "the art of couplehood".

Beyond the fact that The Enigma of Childhood is a fascinating book for psychiatrists and psychologists, who will find in it innovations on the mental world in which old concepts are presented in new garb, this is a book that every general practitioner or pediatrician is likely to find of interest in dealing with issues such as: constipation, enuresis, weaning, angry outbursts, stranger anxiety, abandonment anxiety, nightmares, acts of compulsion, phobias, suspiciousness, intimacy, happiness, and couplehood. I warmly recommend the book to anyone who would like to take a deeper look at "the child within him", at his own child and his life partner, and who is interested in improving his understanding of them and his relationship with them.

All that remains is for us to wait for the continuation of the description of development from the oedipal phase onward. *Corresponding author: Solan R, Tel Aviv University, Israel, Tel: +972 9-747-8532;
E-mail: ronnie.solan@gmail.com

Received June 20, 2016; Accepted June 23, 2016; Published June 28, 2016

Citation: Solan R, Gaoni B (2016) The Enigma of Childhood the Profound Impact of the First Years of Life on Adults as Couples and Parents. J Ment Disord Treat 2: 111. doi:10.4172/2471-271X.1000111

Copyright: ( 2016 Solan R, et al. This is an open-access article distributed under the terms of the Creative Commons Attribution License, which permits unrestricted use, distribution, and reproduction in any medium, provided the original author and source are credited. 